\title{
Levels of clonal mixing in the black bean aphid Aphis fabae, a facultative ant mutualist
}

\author{
A. VANTAUX, J. BILLEN and T. WENSELEERS \\ Laboratory of Entomology, Zoological Institute, Catholic University of Leuven, Naamsestraat 59, B-3000 Leuven, Belgium
}

\begin{abstract}
Aphids are a worldwide pest and an important model in ecology and evolution. Little is known, however, about the genetic structure of their colonies at a microgeographic level. For example, it remains largely unknown whether most species form monoclonal or polyclonal colonies. Here, we present the first detailed study on levels of clonal mixing in a nonsocial facultative ant mutualist, the black bean aphid Aphis fabae. In contrast to the earlier suggestion that colonies of this species are generally monoclonal, we found that across two subspecies of the black bean aphid, A. fabae cirsiiacanthoidis and A. fabae fabae, $32 \%$ and $67 \%$ of the aphid colonies were in fact polyclonal, consisting of a mix of up to four different clones, which resulted in an overall average relatedness within colonies of 0.90 and 0.79 in the two subspecies. Data further show that the average relatedness in $A$. f. cirsiiacanthoidis remained relatively constant throughout the season, which means that clonal erosion due to clonal selection more or less balanced with the influx of new clones from elsewhere. Nevertheless, relatedness tended to decrease over the lifetime of a given colony, implying that clonal mixing primarily resulted from the joining of pre-existing colonies as opposed to via simultaneous host colonisation by several foundresses. Widespread clonal mixing is argued to affect the ecology and evolution of the aphids in various important ways, for example with respect to the costs and benefits of group living, the evolution of dispersal and the interaction with predators as well as with the ant mutualists.
\end{abstract}

Keywords: competition, dispersal, Hemiptera, kin structure, relatedness

Received 4 February 2011; revision received 16 June 2011; accepted 24 June 2011

\section{Introduction}

Aphids are considered to be one of the most devastating pests in both agriculture and horticulture (Minks \& Harrewijn 1987). In addition, their highly polyphagous nature and probing feeding behaviour causes many to be important vectors of plant viruses. Their cyclical parthenogenetic life cycle enables them to achieve a tremendous growth rate and the numerous interactions with other organisms make them an excellent model in ecology and evolution. Population genetic studies, for example, have been conducted on topics such as host plant specialisation (Via 1991; Ferrari et al. 2008), sympatric speciation (Via 2009) and the advantage of sexual reproduction (Guillemaud et al. 2003; Simon et al.

Correspondence: Amélie Vantaux, Fax: +32 16 324575; E-mail: amelie.vantaux@gmail.com
2010), with the pea aphid being one of the key models used in this area. Despite the multitude of population genetic studies that have been conducted on aphids, however, detailed studies on the genetic structure of their colonies at a microgeographic level remain sparse. As aphids reproduce asexually in spring and summer, colonies have long been considered to consist of genetically identical individuals, i.e. of progeny derived from a single foundress (Mackenzie 1996; Hodgson 2001; Wu et al. 2010). Studies on the genetic structure of aphid colonies, however, have revealed significant variation in their composition. Some older allozyme and DNA fingerprinting studies, for example, have inferred aphid colonies to be monoclonal (in Aphis fabae, Mackenzie 1996), while others have shown varying levels of polyclonality (in Sitobion fragariae, Loxdale \& Brookes 1990; and Schizaphis graminum, Shufran et al. 1991; in Sitobion avenae, De Barro et al. 1994; in Myzus persicae, Fenton 
et al. 1998). Nevertheless, these studies employed markers with low variability and were mostly based on rather limited sample sizes, which probably resulted in an underestimation of natural levels of clonal mixing. A handful of more recent microsatellite studies have also revealed contrasting patterns with respect to levels of clonal mixing found in aphid populations. For example, one study on the invasive Oleander aphid Aphis nerii inferred colonies to be monoclonal and composed of one of two 'superclones', which dominated that particular study population (Harrison \& Mondor 2011). By contrast, significant levels of clonal mixing were found in studies on two obligately asexual Sitobion species (Wilson et al. 1999), Pemphigus social gall aphids (Abbot et al. 2001; Johnson et al. 2002; Abbot 2009) and two autoecious species, which complete their entire life cycle on the same host plant - the obligate ant mutualist Tuberculatus quercicola (Yao \& Akimoto 2009) and the untended species Macrosiphonella tanacetaria (Massonnet \& Weisser 2004; Loxdale et al. 2011). Nevertheless, all of these species have a rather peculiar lifestyle, being either obligately asexual or completing most of their life cycle in a closed environment. Hence, for most free-living (nonautoecious and nonsocial, nongalling) aphid species, the extent of clonal mixing in natural populations remains largely unknown. On an a priori basis, one might expect colonies of such species to form monoclonal colonies if alates were able to preferentially colonise unoccupied host plants, whereas in situations where all plants were occupied, or where several alates would simultaneously colonise the same host plants, significant levels of clonal mixing should be seen.

The limited information on the sociogenetic structure of aphid colonies is surprising given that it is expected to have very important consequences for their ecology and evolution (Loxdale 2008). For example, dispersal in aphids by either alates or apterous individuals has so far been shown to be induced by a decrease in host plant quality (Harrington \& Taylor 1990; Hodgson 1991; Howard \& Dixon 1992), the presence of natural enemies and the production of alarm pheromone (Dixon \& Agarwala 1999; Weisser et al. 1999; Sloggett \& Weisser 2002; Kunert et al. 2005, 2007, 2008; Hatano et al. 2010) or crowding effects (Lees 1966; Sutherland 1969; Dixon 1977; Harrison 1980; Mousseau \& Dingle 1991; Moran 1992; Dixon 1998; Müller et al. 2001; for reviews see Braendle et al. 2006; Kunert et al. 2007). Nevertheless, inclusive fitness theory has shown that dispersal can also to a large extent be driven by competition with relatives (Hamilton \& May 1977; Frank 1986; Taylor 1988; Plantegenest \& Kindlmann 1999; Ronce et al. 2000; Perrin \& Goudet 2001). This implies that levels of clonal mixing could have important consequences for the evo- lution of dispersal in aphids. For example, populations with a lot of clonal mixing would be expected to have a reduced or delayed dispersal relative to those where all colonies are monoclonal (for two specific model that demonstrate this for aphids see Ozaki 1995 and Plantegenest \& Kindlmann 1999). In addition, inclusive fitness theory predicts that in multiclonal colonies, there should be less selection on altruistic behaviour (Hamilton 1964a,b, 1987) such as that which is seen in some species that produce nonreproductive soldiers, such as some gall aphids and some soldier-producing secondary-host aphid species (e.g. Pseudoregma) (Stern \& Foster 1996; Pike \& Foster 2008).

Despite the fact that the degree of clonal mixing would be expected to have such important consequences for the ecology and evolution of aphid populations, the genetic colony structure of free-living nonautoecious aphid species has as yet not been thoroughly studied. Hence, the aim of this study was to determine the genetic structure of colonies of two subspecies of the black bean aphid, Aphis fabae cirsiiacanthoidis and A. fabae fabae, which are nonsocial, freeliving aphids that most commonly engage in a facultative mutualism with the black garden ant Lasius niger (Stadler \& Dixon 1998, 1999; Völkl et al. 1999; Offenberg 2001; Stadler et al. 2002; Woodring et al. 2004; Detrain et al. 2010). We were interested in deciphering their colony structure in the field, as this might have important consequences for the evolution of optimal dispersal, reproductive competition within the aphid colonies, as well as for their interaction with ant mutualists. We also tested whether the clonal diversity of the aphid colonies increased with the colony lifespan, attributed to the arrival of new winged individuals from elsewhere, or with the progression of the season, because of the greater scarcity of uncolonised host plants, which would force winged aphids to join pre-existing colonies.

\section{Materials and methods}

\section{Study species}

Aphis fabae represents a complex of at least four subspecies, which all reproduce sexually on the same primary host plants, primarily Euonymus europaeus, but also, to a lesser extent, Viburnum opulus and Philadelphus coronarius. The asexually reproducing summer generations, however, are extremely polyphagous, although the occurrence on particular host plant species can be used to define subspecies (Stroyan 1984). For example, black bean aphids occurring on the summer host plant Cirsium arvense are referred to as $A$. fabae cirsiiacanthoidis and those occurring on Vicia faba as A. fabae fabae. 


\section{Sampling}

Aphis fabae cirsiiacanthoidis individuals were collected from thistle (Cirsium arvense) on a study plot of 0.6 ha in Kortrijk (Belgium). This study site is a natural area owned by KU Leuven. It is only ploughed once a year, and it is mainly surrounded by university buildings with the exception of agricultural fields on one side. Sampling was carried out between 12 May 2009 and 7 July 2009, which correspond to the first and last observations of this species in our study plot. We also collected information on the presence or absence of ants (only Lasius niger visited our aphid colonies) and natural enemies (ladybirds, syrphid larvae and parasitoid wasps) when each colony was sampled. In our study plot, Lasius niger was observed to tend A. fabae cirsiiacanthoidis only at the beginning of the sampling season, and then rapidly moved over to tending Brachycaudus sp., as was also observed in other studies (Fischer et al. 2001). From 31 plants, all the winged and unwinged adults were sampled, which resulted in the collection of a total of 432 individuals. In addition, seven randomly selected plants were sampled repeatedly once a week until any given colony disappeared. In this case, we collected all the winged individuals that were present plus 4-9 randomly selected unwinged adults, resulting in the sampling of a total of 190 individuals. All winged individuals correspond to alate viviparae, which disperse among secondary host plants. In addition, a further nine colonies of $A$. fabae fabae (87 individuals) were collected from Vicia faba plants grown in spring and summer 2010 in private gardens in the surrounding of Leuven (Belgium), and which were nearly all tended by L. niger at the time they were sampled. All aphids were stored in $100 \%$ ethanol at $4{ }^{\circ} \mathrm{C}$ until further analysis.

\section{DNA extraction and genotyping}

DNA was extracted using the Chelex method (Walsh et al. 1991), in which each aphid was first snap frozen in liquid nitrogen and ground up using a plastic pestle, followed by a 15 -min incubation at $95^{\circ} \mathrm{C}$ in $200 \mu \mathrm{L}$ of $10 \%$ Biorad Chelex ${ }^{\circledR}$ 100TM resin solution. Samples were vortexed and centrifuged before use.

Polymerase chain reactions (PCR) amplifications were performed in $10 \mu \mathrm{L}$ of reaction mixture containing $1 \mu \mathrm{L}$ of crude DNA extract from a single individual, $1.5 \mathrm{~mm}$ $\mathrm{MgCl}_{2}\left(\mathrm{MgCl}_{2}\right.$; Eurogentec), $0.5 \mu \mathrm{M}$ of the forward and reverse primers (Applied Biosystems and Eurogentec), $0.2 \mathrm{~mm}$ of each dNTP (dNTP Set; Fermentas), 0.6 units of Silverstar Taq polymerase (Eurogentec) and $1 \times$ of enzyme buffer supplied by the manufacturer.

All samples were genotyped at seven loci, AfF, Ago59, Af82, Afl, AfBeta, Af134 and Af181 (Vanlerberghe-Mas- utti et al. 1999; Coeur d'Acier et al. 2004; Gauffre \& D'Acier 2006). In one PCR, PCR A, we multiplexed loci Af82, Afl, AfBeta, Af134, Af181, and in a second and third PCR B and C, we amplified loci Ago59 and AfF, respectively. All PCRs were performed following a touch-down program, with an initial activation step of $3 \mathrm{~min}$ at $94^{\circ} \mathrm{C}$, followed by 19 cycles consisting of a denaturation step of $30 \mathrm{~s}$ at $94{ }^{\circ} \mathrm{C}$, annealing for $90 \mathrm{~s}$ at $60{ }^{\circ} \mathrm{C}$ (PCR A and C) or $57^{\circ} \mathrm{C}$ (PCR B), decreasing $0.5^{\circ} \mathrm{C}$ in each step, and a $60 \mathrm{~s}$ (PCR A and C) or $45 \mathrm{~s}$ (PCR B) extension at $72{ }^{\circ} \mathrm{C}$, nine cycles consisting of $30 \mathrm{~s}$ at $94{ }^{\circ} \mathrm{C}, 30 \mathrm{~s}$ at $46{ }^{\circ} \mathrm{C}$ and $45 \mathrm{~s}$ at $72{ }^{\circ} \mathrm{C}$, and a 10 -min extension step at $72{ }^{\circ} \mathrm{C}$ followed by a final extension for $30 \mathrm{~min}$ at $60{ }^{\circ} \mathrm{C}$ (PCR A and B) or $72{ }^{\circ} \mathrm{C}$ (PCR C).

After amplification, the PCR products of PCR A and of PCRs B and C were mixed with formamide and Genescan 500 LIZ size standard (Applied Biosystems), denatured, and loaded in two separate runs onto an ABI-3130 Avant capillary sequencer. Alleles were called using the supplied Gene Mapper software (GeneMapper $^{\circledR} ;$ Applied Biosystems). Potential genotyping mistakes were identified using the program GenClone (Arnaud-Haond \& Belkhir 2007), and suspect samples were regenotyped twice, after which the consensus genotype was used for further analysis.

\section{Analysis of levels of clonal mixing}

Different clones were identified based on their multilocus genotypes. The power to be able to discriminate among different clones using the seven loci we used was calculated as one minus the probability that different clones would have identical multilocus genotypes by chance, which is given as $1-\Pi\left(1-H_{\mathrm{e}}\right)$, where $H_{\mathrm{e}}$ is the expected heterozygosity at the $i$ th locus and the product is taken over all loci. The observed clonal diversity $C D_{0}$, i.e. the effective number of clones present on each plant, accounting for unequal representation, was calculated as the inverse of the Simpson index (Lande 1996), i.e. as $1 / \sum_{\mathrm{i}} p_{\mathrm{i}}^{2}$ where $p_{\mathrm{i}}$ is the relative frequency of the $i$ th clone's multilocus genotype. In addition, when colonies could not be sampled completely, we calculated the nonsampling-corrected clonal diversity $\mathrm{CD}_{\mathrm{c}}$, as $[n-1]^{2} /\left(\sum_{i}\left[p_{i}\right]^{2}(n+1)(n-2)+3-n\right)$, where $n$ is the number of aphids that were sampled (Nielsen et al. 2003). Deviations of the clonal diversity from Hardy-Weinberg $(\mathrm{H}-\mathrm{W})$ expectations were tested for using a randomization test implemented in the software Hwclon (De Meester \& Vanoverbeke 1999). This test calculates deviations of the observed clonal diversity from the clonal diversity expected based on a large number of permutations of the original sample. A new sample of the same size and with the same number of copies of each allele is then created after random distri- 
bution of the alleles over the individuals at each locus (De Meester \& Vanoverbeke 1999).

SPAGeDI (Hardy \& Vekemans 2002) was used to calculate the genetic differentiation among samples based on $F_{\mathrm{ST}}$ values (Weir \& Cockerham 1984) and to test whether the pairwise regression relatedness among the aphids decreased with the distance among their colonies. The latter was performed by regressing pairwise regression relatedness on the linear distance for all possible pairs in the population. Standard errors on these estimates were calculated by jackknifing over loci. In addition, we calculated the average regression relatedness $r$ among aphids collected on the same plant using Relatedness (Queller \& Goodnight 1989), as well as pedigree relatedness values $r_{p}$, which were calculated as the inverse of the observed or corrected clonal diversity for plants that could or could not be sampled completely, respectively. Regression relatedness is a statistical leastsquare regression-based estimator of genetic relatedness (Queller \& Goodnight 1989), which in our case should match pedigree relatedness provided that selection is weak and that the different clones coexisting on the sample plant would be unrelated to one another. In some cases, the aphid colonies formed spatially segregated groups on the different branches of a plant. In these cases, we also calculated the regression relatedness among the aphids present on a given part of the plant and tested whether it was significantly higher than that among the aphids present on the whole plant using a Wilcoxon matched pairs test. For all A. fabae cirsiiacanthoidis colonies that were sampled repeatedly and which became polyclonal over time, we used a mixed-model General Linear Model (GLM) to test whether the colony regression relatedness was related to seasonal progression or the time after the colony was first sampled, with plant being coded as a random blocking factor. In addition, for all our A. fabae cirsiiacanthoidis samples, we used GLMs to test whether the average regression relatedness was linked with seasonal progression, colony size and the presence or absence of ants or natural enemies. All statistical tests were performed using Statistica 9.1 (StatSoft, Inc.). Unless noted, all reported tests are two-tailed, and permutation tests were run 10000 times.

\section{Results}

Levels of clonal mixing and genetic differentiation in A. f. cirsiiacanthoidis and A. f. fabae

The number of alleles per locus at the seven loci used ranged from 6 to 22 (avg. 13.57) and from 5 to 9 (avg. 8.14), and the expected heterozygosity correcting for sample size $\left(H_{\mathrm{e}}\right)$ ranged from 0.43 to 0.91 (avg. 0.79) and from 0.64 to 0.82 (avg. 0.75) in A. f. cirsiiacanthoidis and A. f. fabae, respectively (Table 1). This resulted in an extremely good power, of $99.9994 \%$ and $99.995 \%$ in the two subspecies, to be able to discriminate among any two different clones based on their multilocus genotype. In addition, clones differed at an average number of 5.4-6.4 and 6.4 loci in A. f. cirsiiacanthoidis and A. f. fabae, respectively (Tables 2 and 3). Of the A. f. cirsiiacanthoidis colonies which were sampled once, ca. $32 \%$ (10 out of 31 ) were polyclonal, consisting of a mix of two or three clones (Table 2, Fig. 1), resulting in an overall harmonic average observed clonal diversity per plant of $1.12( \pm 0.04 \mathrm{SE})$ and an arithmetic average pedigree and regression relatedness among aphids present on the same plant of $r_{\mathrm{p}}=0.92 \pm 0.02 \mathrm{SE}$ and $r=0.89 \pm 0.008$ SE (Table 2). Similar results were obtained for the A.f. cirsiiacanthoidis colonies, which were sampled repeatedly, where initially $14 \%$ ( 1 out of

Table 1 Per-locus summary statistics for Aphis fabae cirsiiacanthoidis and Aphis fabae fabae colonies that were collected and genotyped in their entirety, indicating the number of adults genotyped $(n)$, the number of alleles per locus $(A)$, expected heterozygosity $\left(H_{\mathrm{e}}\right)$, the mean allele size $\left(M_{\mathrm{A}}\right)$, the variance of the allele size $\left(\mathrm{V}_{\mathrm{A}}\right)$ and the average $F_{\mathrm{ST}}$ values

\begin{tabular}{|c|c|c|c|c|c|c|c|c|c|c|c|c|}
\hline \multirow[b]{2}{*}{ Locus } & \multicolumn{6}{|c|}{ A. fabae cirsiiacanthoidis } & \multicolumn{6}{|c|}{ A. fabae fabae } \\
\hline & $n$ & $A$ & $H_{\mathrm{e}}$ & $M_{\mathrm{A}}$ & $V_{\mathrm{A}}$ & $F_{\mathrm{ST}}$ & $n$ & $A$ & $H_{\mathrm{e}}$ & $M_{\mathrm{A}}$ & $V_{\mathrm{A}}$ & $F_{\mathrm{ST}}$ \\
\hline AfF & 432 & 10 & 0.7916 & 127.0 & 49.0 & 0.6270 & 87 & 9 & 0.7745 & 121.1 & 56.1 & 0.4475 \\
\hline Ago59 & 432 & 17 & 0.8751 & 173.8 & 126.5 & 0.5176 & 87 & 9 & 0.8221 & 174.6 & 82.5 & 0.6266 \\
\hline Af82 & 432 & 14 & 0.8523 & 182.1 & 99.8 & 0.4732 & 87 & 9 & 0.7624 & 194.7 & 404.6 & 0.5545 \\
\hline AfI & 432 & 6 & 0.4350 & 234.3 & 84.7 & 0.4978 & 87 & 8 & 0.6944 & 236.3 & 33.7 & 0.5700 \\
\hline AfBeta & 432 & 22 & 0.9097 & 291.3 & 177.8 & 0.5748 & 87 & 8 & 0.7763 & 285.7 & 65.0 & 0.3749 \\
\hline Af134 & 432 & 13 & 0.7986 & 294.8 & 128.2 & 0.7181 & 87 & 9 & 0.7892 & 299.6 & 224.1 & 0.6400 \\
\hline Af181 & 432 & 13 & 0.8587 & 315.1 & 36.7 & 0.5519 & 87 & 5 & 0.6409 & 313.3 & 29.7 & 0.3912 \\
\hline Average & & 13.57 & 0.7887 & 231.2 & 100.4 & 0.5690 & & 8.14 & 0.7514 & 232.19 & 127.96 & 0.5210 \\
\hline $\mathrm{SE}^{*}$ & & & & & & 0.0319 & & & & & & 0.0417 \\
\hline
\end{tabular}

*Calculated by jackknifing over loci. 
Table 2 Data on the genetic structure of the Aphis fabae cirsiiacanthoidis colonies that were studied on plants which were sampled once and collected and genotyped in their entirety, showing plant code, sampling date, the morphs that were present (unwinged, U, or winged, W), whether the winged individuals were emigrants $(E)$ or immigrants $(I)$, the total number of adults genotyped $(n)$, the number of clones that were present $(c)$, the average number of loci at which clones differed $(L)$, observed clonal diversity $\left(\mathrm{CD}_{\mathrm{o}}\right.$, i.e. the effective number of clones which were present, accounting for unequal representation) and mean pedigree relatedness $r_{\mathrm{p}}$ (calculated as $1 / \mathrm{CD}_{\mathrm{o}}$ ) and regression relatedness $r$ (Queller \& Goodnight 1989) among the aphids on a given plant

\begin{tabular}{|c|c|c|c|c|c|c|c|c|c|c|}
\hline Plants & Date & Morphs & $E$ & $I$ & $n$ & c & $L$ & $\mathrm{CD}_{\mathrm{o}}$ & $r_{\mathrm{p}}$ & $r\left(\mathrm{SE}^{*}\right)$ \\
\hline AC1-12-06 & $12 / 06$ & $\mathrm{U}$ & & & 14 & 1 & & 1 & 1 & 1 \\
\hline AC1-19-05 & $19 / 05$ & $\mathrm{U}$ & & & 5 & 2 & 1 & 1.47 & 0.68 & $0.97(0.03)$ \\
\hline \multirow[t]{3}{*}{ AC1-27-05 } & $27 / 05$ & $\mathrm{U}+\mathrm{W}$ & & & 14 & 1 & & 1 & 1 & 1 \\
\hline & & $\mathrm{U}$ & & & 7 & 1 & & 1 & 1 & 1 \\
\hline & & $\mathrm{W}$ & 7 & & 7 & 1 & & 1 & 1 & 1 \\
\hline \multirow[t]{3}{*}{ AC1-03-06 } & $03 / 06$ & $\mathrm{U}+\mathrm{W}$ & & & 14 & 1 & & 1 & 1 & 1 \\
\hline & & $\mathrm{U}$ & & & 7 & 1 & & 1 & 1 & 1 \\
\hline & & $\mathrm{W}$ & 7 & & 7 & 1 & & 1 & 1 & 1 \\
\hline AC1-13-05 & $13 / 05$ & $\mathrm{U}$ & & & 3 & 1 & & 1 & 1 & 1 \\
\hline AC2-17-06 & $17 / 06$ & $\mathrm{U}$ & & & 3 & 1 & & 1 & 1 & 1 \\
\hline \multirow[t]{3}{*}{ AC2-27-05 } & $27 / 05$ & $\mathrm{U}+\mathrm{W}$ & & & 34 & 2 & 5 & 1.06 & 0.94 & $0.97(0.01)$ \\
\hline & & $\mathrm{U}$ & & & 31 & 2 & 5 & 1.07 & 0.94 & $0.97(0.01)$ \\
\hline & & W & & & 3 & 1 & & 1 & 1 & 1 \\
\hline \multirow[t]{3}{*}{ AC2-03-06 } & $03 / 06$ & $\mathrm{U}+\mathrm{W}$ & & & 22 & 2 & 7 & 2 & 0.5 & $0.54(0.14)$ \\
\hline & & $\mathrm{U}$ & & & 19 & 2 & 7 & 1.95 & 0.51 & $0.56(0.14)$ \\
\hline & & $\mathrm{W}$ & & & 3 & 1 & & 1 & 1 & 1 \\
\hline \multirow[t]{3}{*}{ AC2-13-05 } & $13 / 05$ & $\mathrm{U}+\mathrm{W}$ & & & 8 & 2 & 7 & 1.28 & 0.78 & $0.72(0.04)$ \\
\hline & & $\mathrm{U}$ & & & 7 & 1 & & 1 & 1 & 1 \\
\hline & & $\mathrm{W}$ & & 1 & 1 & 1 & & 1 & 1 & 1 \\
\hline AC2-19-05 & $19 / 05$ & $\mathrm{U}$ & & & 8 & 1 & & 1 & 1 & 1 \\
\hline AC2-12-06 & $12 / 06$ & $\mathrm{U}$ & & & 19 & 1 & & 1 & 1 & 1 \\
\hline AC3-27-05 & $27 / 05$ & $\mathrm{U}$ & & & 6 & 1 & & 1 & 1 & 1 \\
\hline AC3-03-06 & 03/06 & $\mathrm{U}$ & & & 6 & 1 & & 1 & 1 & 1 \\
\hline AC3-12-06 & $12 / 06$ & $\mathrm{U}$ & & & 11 & 3 & $6.7(6-7)$ & 1.46 & 0.69 & $0.64(0.03)$ \\
\hline BC1-12-06 & $12 / 06$ & $\mathrm{U}$ & & & 9 & 2 & 1 & 1.53 & 0.65 & $0.38(0.05)$ \\
\hline BC1-17-06 & $17 / 06$ & $\mathrm{U}$ & & & 6 & 1 & & 1 & 1 & 1 \\
\hline BC1-03-06 & 03/06 & $\mathrm{U}$ & & & 20 & 1 & & 1 & 1 & 1 \\
\hline \multirow[t]{3}{*}{ BC1-13-05 } & $13 / 05$ & $\mathrm{U}+\mathrm{W}$ & & & 13 & 2 & 6 & 1.17 & 0.86 & $0.86(0.03)$ \\
\hline & & $\mathrm{U}$ & & & 11 & 1 & & 1 & 1 & 1 \\
\hline & & $\mathrm{W}$ & 1 & 1 & 2 & 2 & 6 & 2.00 & 0.50 & $-0.01(0.14)$ \\
\hline \multirow[t]{3}{*}{ BC1-27-05 } & $27 / 05$ & $\mathrm{U}+\mathrm{W}$ & & & 22 & 1 & & 1 & 1 & 1 \\
\hline & & $\mathrm{U}$ & & & 15 & 1 & & 1 & 1 & 1 \\
\hline & & W & 7 & & 7 & 1 & & 1 & 1 & 1 \\
\hline BC2-03-06 & 03/06 & $\mathrm{U}$ & & & 6 & 1 & & 1 & 1 & 1 \\
\hline \multirow[t]{3}{*}{ BC2-12-06 } & $12 / 06$ & $\mathrm{U}+\mathrm{W}$ & & & 32 & 1 & & 1 & 1 & 1 \\
\hline & & $\mathrm{U}$ & & & 20 & 1 & & 1 & 1 & 1 \\
\hline & & W & 12 & & 12 & 1 & & 1 & 1 & 1 \\
\hline BC2-17-06 & $17 / 06$ & $\mathrm{U}$ & & & 13 & 1 & & 1 & 1 & 1 \\
\hline BC2-27-05 & $27 / 05$ & $\mathrm{U}$ & & & 22 & 1 & & 1 & 1 & 1 \\
\hline \multirow[t]{3}{*}{ ВC3-03-06 } & 03/06 & $U+W$ & & & 16 & 1 & & 1 & 1 & 1 \\
\hline & & $\mathrm{U}$ & & & 13 & 1 & & 1 & 1 & 1 \\
\hline & & $\mathrm{W}$ & 3 & & 3 & 1 & & 1 & 1 & 1 \\
\hline \multirow[t]{3}{*}{ BC3-12-06 } & $12 / 06$ & $\mathrm{U}+\mathrm{W}$ & & & 21 & 3 & $5(1-7)$ & 1.21 & 0.82 & $0.89(0.01)$ \\
\hline & & $\mathrm{U}$ & & & 7 & 3 & $5(1-7)$ & 1.81 & 0.55 & $0.66(0.07)$ \\
\hline & & $\mathrm{W}$ & 14 & & 14 & 1 & & 1 & 1 & 1 \\
\hline \multirow[t]{3}{*}{ ВС3-13-05 } & $13 / 05$ & $\mathrm{U}+\mathrm{W}$ & & & 9 & 2 & 6 & 1.25 & 0.80 & $0.82(0.07)$ \\
\hline & & $\mathrm{U}$ & & & 8 & 2 & 6 & 1.28 & 0.78 & $0.79(0.08)$ \\
\hline & & $\mathrm{W}$ & 1 & & 1 & 1 & & 1 & 1 & 1 \\
\hline ВС5-19-05 & $19 / 05$ & $\mathrm{U}$ & & & 11 & 1 & & 1 & 1 & 1 \\
\hline CC2-13-05 & $13 / 05$ & $\mathrm{U}$ & & & 9 & 1 & & 1 & 1 & 1 \\
\hline
\end{tabular}


Table 2 (Continued)

\begin{tabular}{|c|c|c|c|c|c|c|c|c|c|c|}
\hline Plants & Date & Morphs & E & $I$ & $n$ & $c$ & $L$ & $\mathrm{CD}_{\mathrm{o}}$ & $r_{\mathrm{p}}$ & $r\left(\mathrm{SE}^{*}\right)$ \\
\hline \multirow[t]{3}{*}{ CC3-13-05 } & $13 / 05$ & $U+W$ & & & 13 & 2 & 5 & 1.17 & 0.86 & $0.46(0.07)$ \\
\hline & & $\mathrm{U}$ & & & 12 & 1 & & 1 & 1 & 1 \\
\hline & & W & & 1 & 1 & 1 & & 1 & 1 & 1 \\
\hline CC7-19-05 & $19 / 05$ & $\mathrm{U}$ & & & 18 & 1 & & 1 & 1 & 1 \\
\hline \multirow[t]{3}{*}{ СС9-19-05 } & $19 / 05$ & $\mathrm{U}+\mathrm{W}$ & & & 25 & 1 & & 1 & 1 & 1 \\
\hline & & $\mathrm{U}$ & & & 24 & 1 & & 1 & 1 & 1 \\
\hline & & $\mathrm{W}$ & 1 & & 1 & 1 & & 1 & 1 & 1 \\
\hline Average & & All & & & $13.94^{+}$ & $1.39^{+}$ & 5.4 & $1.12^{\ddagger}$ & $0.92^{+}$ & $0.89^{\dagger}$ \\
\hline SE & & All & & & 1.44 & 0.11 & & 0.04 & 0.02 & 0.008 \\
\hline Average & & $\mathrm{U} / \mathrm{W}$ & & & & & & & $0.90 / 0.96$ & $0.89 / 0.96$ \\
\hline SE & & $\mathrm{U} / \mathrm{W}$ & & & & & & & $0.05 / 0.04$ & $0.008 / 0.006$ \\
\hline
\end{tabular}

*Calculated by jackknifing over loci.

${ }^{+}$Arithmetic average.

${ }^{\ddagger}$ Harmonic average.

Table 3 Data on the genetic structure of Aphis fabae fabae colonies collected from bean plants and genotyped in their entirety, showing plant code, sampling date, the number of adults genotyped $(n)$, the number of clones present $(c)$, the average number of loci at which clones differed $(L)$, the observed clonal diversity $\left(\mathrm{CD}_{\mathrm{o}}\right.$, i.e. the effective number of clones which were present), the mean pedigree relatedness $r_{\mathrm{p}}$ (calculated as 1/CD ) and regression relatedness $r$ (Queller \& Goodnight 1989) among the aphids on a given plant at a particular point in time and whether or not the study colonies were tended by ants

\begin{tabular}{lllllllll}
\hline Plants & Date & $n$ & $c$ & $L$ & $\mathrm{CD}_{\mathrm{o}}$ & $r_{\mathrm{p}}$ & $r\left(\mathrm{SE}^{*}\right)$ & Ant tended \\
\hline B1 & $15 / 07$ & 10 & 2 & 6 & 1.21 & 0.82 & $0.91(0.03)$ & No \\
B2 & $28 / 06$ & 18 & 1 & & 1 & 1 & 1 & Yes \\
B3 & $28 / 06$ & 6 & 1 & & 1 & 1 & 1 & Yes \\
B4 & $28 / 06$ & 7 & 2 & 7 & 1.32 & 0.76 & $0.74(0.04)$ & Yes \\
B5 & $28 / 06$ & 5 & 2 & 6 & 1.47 & 0.68 & $0.63(0.05)$ & Yes \\
B6 & $28 / 06$ & 4 & 2 & 7 & 2 & 0.50 & $0.33(0.10)$ & Yes \\
B7 & $28 / 06$ & 3 & 1 & & 1 & 1 & 1 & Yes \\
B8 & $05 / 07$ & 17 & 4 & $6.7(5-7)$ & 1.65 & 0.61 & $0.60(0.03)$ & Yes \\
B9 & $06 / 07$ & 17 & 3 & $5.7(5-7)$ & 2.08 & 0.48 & $0.65(0.05)$ & Yes \\
Average & & $9.67^{+}$ & $2.00^{+}$ & 6.4 & $1.32^{\ddagger}$ & $0.73^{+}$ & $0.79^{+}$ & 0.09 \\
SE & & 2.03 & 0.33 & & 0.14 & 0.07 & \\
\hline
\end{tabular}

${ }^{*}$ Calculated by jackknifing over loci.

${ }^{+}$Arithmetic average.

${ }^{\ddagger}$ Harmonic average.

7) were polyclonal, but a further three became polyclonal $(57 \%)$ on subsequent samplings, and where a mix of up to three clones co-occurred on the same plants (Table 4, Fig. 2). The overall harmonic average observed and corrected clonal diversity per plant were $1.18( \pm 0.09 \mathrm{SE})$ and $1.16( \pm 0.12 \mathrm{SE})$, and the arithmetic average pedigree and regression relatedness were estimated at $r_{\mathrm{p}}=0.86 \pm 0.05 \mathrm{SE}$ and $r=0.86 \pm 0.008 \mathrm{SE}$ (Table 4). Of the A.f. fabae colonies collected from $V$. faba, ca. $67 \%$ (6 out of 9) were polyclonal, consisting of a mix of two to four clones (Table 3). The overall harmonic average observed clonal diversity per plant was $1.32( \pm 0.14 \mathrm{SE})$ and the arithmetic average pedigree and regression relatedness among aphids present on the same plant were estimated at $r_{\mathrm{p}}=0.73 \pm 0.07 \mathrm{SE}$ and $r=0.79 \pm 0.09 \mathrm{SE}$ (Table 3). Neither colony size, the presence of ants or the presence of natural enemies had a significant effect on relatedness in the A. f. cirsiiacanthoidis colonies which were sampled once (colony size: $F_{1,29}=0.56, P=0.46$; ants: $F_{1,29}=0.07, P=0.13$ and natural enemies: $F_{1,29}=0.03, P=0.33$, respectively) or in the colonies which were sampled repeatedly over time (colony size: $F_{1,9}=0.07, P=0.93$; natural enemies: $F_{1,9}=2.06, P=0.18$ ). The average regression relatedness was not significantly different between winged and unwinged individuals in the A. f. cirsiiacanthoidis colonies 


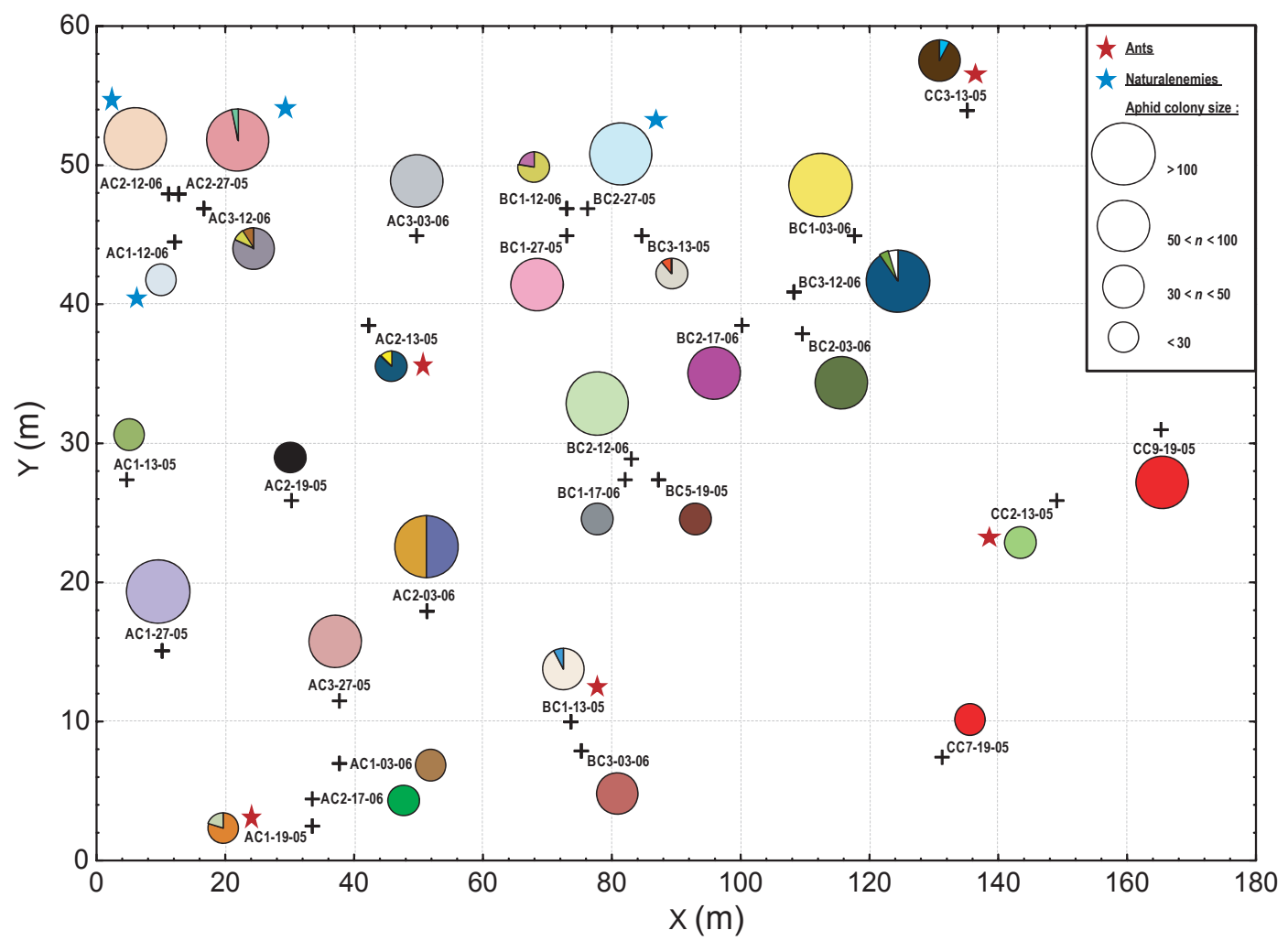

Fig. 1 Genetic structure of the Aphis fabae cirsiiacanthoidis colonies that were studied on plants which were sampled once and collected and genotyped in their entirety, showing the location within the study plot, the plant codes, sampling dates and the presence or absence of ants and natural enemies. The sizes of the pie charts are proportional to the estimated aphid colony sizes, and the sectors display the proportional representation of each clone, whereby different colours are used for each clone.

that were sampled once $\left(F_{1,1}=0.0001, \quad P=0.99\right.$, Table 2) or in those which were sampled repeatedly over time $\left(F_{1,1}=0.09, P=0.77\right.$, Table 4$)$.

Overall, at the population level, there was very large clonal diversity, with a total of 53 different multilocus genotypes being sampled in A. f. cirsiiacanthoidis, of which only two were recovered from more than one plant (2) (Figs 1 and 2). In addition, the pairwise $F_{\mathrm{ST}}$ tests for genetic differentiation confirm that for both $A$. f. cirsiiacanthoidis and A. f. fabae, there was significant genetic differentiation among all plant pairs $(P<0.001)$. Moreover, all samples from the $A$. f. cirsiiacanthoidis colonies sampled several times and 30 out of 31 samples and all samples taken from the A. f. cirsiiacanthoidis and A. f. fabae colonies sampled once showed significant deviations of multilocus genotype frequencies from $\mathrm{H}-\mathrm{W}$ expectations, hence supporting the presence of a strong population structure at the level of individual plants.

Spatial patterns of relatedness in $\mathrm{A} . \mathrm{f}$. cirsiiacanthoidis

The mean regression relatedness calculated among $A$. $f$. cirsiiacanthoidis aphids collected from different parts of the same plant (mean $=0.95 \pm 0.02 \mathrm{SE}$ ) was marginally higher than that calculated among all aphids present on the whole plant (mean $=0.88 \pm 0.07 \mathrm{SE}$ ) (Wilcoxon matched Pairs test, $n=3$, one-tailed $P=0.05$ ). This shows that there was also a slight amount of genetic differentiation among the aphids present on different parts of the same plant, and that the aphids present on a given branch of a plant were more related among each other than with those present on the rest of the plant. At a larger spatial scale, however, the SPAGeDI analysis showed that pairwise relatedness (Queller \& Goodnight 1989) did not significantly increase with the distance between the plants from which the aphids were sampled, and this was true using either the data from the plants which were sampled only once $\left(R^{2}=0.004, \quad y=-0.06+0.0003 x\right.$, one-tailed $P=0.40$; $n=432$ individuals and 89345 pairs) or those from the plants which were sampled repeatedly $\left(R^{2}=0.111\right.$, $y=-0.41+0.002 x$, one-tailed $P=0.30, n=190$ individuals and 13762 pairs). Similar results were obtained when considering only the unwinged individuals, using either the data from the plants which were sampled only once $\left(R^{2}=0.0006, y=-0.05+0.0001 x\right.$, one-tailed $P=0.80, n=368$ individuals and 64839 pairs) or those 
from the plants which were sampled repeatedly $\left(R^{2}=0.14, \quad y=-0.41+0.003 x, \quad\right.$ one-tailed $P=0.24$, $n=139$ individuals and 7475 pairs). The very low $R^{2}$ values and regression slopes that were obtained in both analyses suggest that there was little or no spatial trend in relatedness across the field site, and no significant isolation by distance.

Patterns of relatedness over time in $\mathrm{A} . \mathrm{f}$. cirsiiacanthoidis

GLM analyses showed that there was no significant effect of seasonal progression on the relatedness of the A.f. cirsiiacanthoidis colonies sampled once $\left(F_{1,29}=0.001, P=0.99\right)$ or of those sampled repeatedly over time $\left(F_{1,1}=1.53, P=0.25\right)$. Nevertheless, a GLM analysis on all colonies that were sampled repeatedly over time and which were found to be polyclonal in at least one of the samplings shows that there was a significant decrease in relatedness, and an increase in the level of clonal mixing, over the lifetime of a given colony $\left(F_{1,1}=6.68\right.$; one-tailed $\left.P=0.04\right)$. This implies that clonal mixing primarily resulted from the joining of pre-existing colonies as opposed to via simultaneous host colonisation by several foundresses. Indeed, our genotyping results revealed several instances of alate immigrants joining pre-existing colonies. For example, of the A.f. cirsiiacanthoidis colonies that were sampled completely, the winged individuals in 53 out of 56 cases were emigrants, having multilocus genotypes that were identical to at least one of the unwinged individuals found on the same plant, but in three cases, we inferred them to immigrants (Table 2). Similarly, for the plants which were sampled repeatedly over time, 49 of 52 winged individuals were emigrants and three were probably immigrants, assuming that they did not share a genotype with one of the resident aphids because of some of the residents not having been sampled (Table 4).

\section{Discussion}

Based on high-resolution microsatellite genotyping, our results show that $32 \%$ and $67 \%$ of the colonies in $A$. fabae cirsiiacanthoidis and A. fabae fabae were polyclonal, consisting of a mix of two to four different clones. This resulted in an average clonal diversity of ca. 1.12-1.16 and 1.32 and of an average relatedness of $0.86-0.89$ and 0.79 in the two subspecies studied. The finding of significant amounts of clonal mixing in A. fabae contrast with allozyme data obtained by Mackenzie (1996), who inferred 15 plants to each contain only a single clone of A. f. fabae. Nevertheless, this result could have been biased by the low resolution of the markers used, as well as by the small sample size of this particular study. Overall, however, it is certainly the case that the levels of clonal mixing that we found were lower than what might be expected for a nonautoecious, nongalling species, where there are few barriers to clonal mixing. Indeed, the levels of clonal mixing, which we found, were actually lower or comparable to those documented for the social gall-forming aphids Pemphigus obesinymphae and P. spirothecae, where all and ca. half of all galls surveyed were polyclonal, and an average of $38 \%$ and $10 \%$ of the aphids of a given gall were found to be unrelated intruders (Abbot et al. 2001; Johnson et al. 2002). This implies that a physical barrier such as a gall may not necessarily be needed in aphids to maintain high levels of relatedness. Given the importance of high relatedness in selecting for altruism, this might explain why there are also some cases known of nongalling species that altruistically produce sterile soldiers, e.g. in the bamboo aphid Pseudoregma bambucicola (Stern \& Foster 1996; Shibao 1998, 1999). In our case, the fact that many colonies turned out to be monoclonal may be explained by the fact that most colonies were initiated by single foundress, and that the limited colony lifetime of only a few weeks provided relatively limited opportunities for unrelated aphids to join colonies. This contrast with the situation in gall aphids, where colonies are long-lived and drifting can occur over the whole length of the season (Abbot et al. 2001; Johnson et al. 2002). Previously, tentative evidence for relatively low levels of clonal mixing was also found in allozyme and DNA fingerprinting studies of the grain aphid Sitobion avenae (23.3-71.2\% of the colonies were polyclonal, De Barro et al. 1994) and the black-berry grain aphid Sitobion fragariae (33\% polyclonal, Loxdale \& Brookes 1990) and in microsatellites studies of the two obligately asexual grass and cereal aphids, Sitobion miscanthi and $S$. near fragariae (Wilson et al. 1999) and the two autoecious aphids, the depranosiphid aphid Tuberculatus quercicola (Yao \& Akimoto 2009) and the tansy aphid Macrosiphonella tanacetaria (Massonnet \& Weisser 2004; Loxdale et al. 2011). In fact, the only free-living aphid species for which very high levels of clonal mixing have been suggested is the greenbug Schizaphis graminum, where the sampling of large colonies (>1000 individuals) from a single leaf resulted in more than $80 \%$ of the population genetic diversity being recovered (Shufran et al. 1991). It is thought that in this species such high levels of mixing were caused by the close proximity of the cereal host plants in an agricultural field, as this might have helped apterous morphs to easily move among plants or be dislodged by wind or rain (Shufran et al. 1991). In our study, no such evidence for extensive mixing at small spatial scales was found, given that (i) the influx of new clones mainly came from outside 
Table 4 Data on the genetic structure of the Aphis fabae cirsiiacanthoidis colonies that were studied on plants which were sampled repeatedly over time, showing plant code, sampling date, the morphs that were sampled (unwinged, U, or winged, W), whether the winged individuals were emigrants $(E)$ or possible immigrants $(I)$, the total number of adults genotyped $(n)$, the number of clones that were present $(c)$, the average number of loci at which clones differed $(L)$, observed clonal diversity $\left(\mathrm{CD}_{\mathrm{o}}\right)$, corrected clonal diversity $\left(\mathrm{CD}_{\mathrm{c}}\right.$, i.e. clonal diversity corrected for nonsampling, Nielsen et al. 2003) and mean pedigree relatedness $r_{\mathrm{p}}\left(\mathrm{calculated}\right.$ as $\left.1 / \mathrm{CD}_{\mathrm{c}}\right)$ and regression relatedness $r$ (Queller \& Goodnight 1989) among the aphids on a given plant at a particular point in time

\begin{tabular}{|c|c|c|c|c|c|c|c|c|c|c|c|}
\hline Plants & Date & Morph & $E$ & I & $n$ & c & $L$ & $\mathrm{CD}_{\mathrm{o}}$ & $\mathrm{CD}_{\mathrm{c}}$ & $r_{\mathrm{p}}$ & $r\left(\mathrm{SE}^{*}\right)$ \\
\hline \multirow[t]{2}{*}{ CA2 } & $27 / 05$ & $\mathrm{U}$ & & & 4 & 1 & & 1 & 1 & 1 & 1 \\
\hline & $3 / 06$ & $\mathrm{U}$ & & & 6 & 1 & & 1 & 1 & 1 & 1 \\
\hline \multirow[t]{4}{*}{ CA3 } & $12 / 06$ & $\mathrm{U}$ & & & 7 & 2 & 7 & 1.96 & 2.19 & 0.46 & $0.33(0.07)$ \\
\hline & $17 / 06$ & $\mathrm{U}+\mathrm{W}$ & & & 6 & 2 & 7 & 1.8 & 2.19 & 0.50 & $0.36(0.07)$ \\
\hline & & $\mathrm{U}$ & & & 4 & 2 & 7 & 2.00 & 2.25 & 0.44 & $0.23(0.08)$ \\
\hline & & $\mathrm{W}$ & 2 & & 2 & 1 & 1 & 1 & 1 & 1 & 1 \\
\hline \multirow[t]{6}{*}{ CA5 } & $17 / 06$ & $\mathrm{U}+\mathrm{W}$ & & & 17 & 1 & & 1 & 1 & 1 & 1 \\
\hline & & $\mathrm{U}$ & & & 7 & 1 & & 1 & 1 & 1 & 1 \\
\hline & & $\mathrm{W}$ & 10 & & 10 & 1 & & 1 & 1 & 1 & 1 \\
\hline & $24 / 06$ & $\mathrm{U}+\mathrm{W}$ & & & 18 & 2 & 7 & 1.38 & 1.41 & 0.70 & $0.68(0.06)$ \\
\hline & & $\mathrm{U}$ & & & 8 & 1 & & 1 & 1 & 1 & 1 \\
\hline & & W & 2 & 3 & 10 & 2 & 7 & 1.72 & 1.84 & 0.54 & $0.50(0.08)$ \\
\hline \multirow[t]{6}{*}{ CB1 } & $3 / 06$ & $\mathrm{U}$ & & & 5 & 1 & & 1 & 1 & 1 & 1 \\
\hline & $12 / 06$ & $\mathrm{U}$ & & & 7 & 1 & & 1 & 1 & 1 & 1 \\
\hline & $17 / 06$ & $\mathrm{U}$ & & & 7 & 1 & & 1 & 1 & 1 & 1 \\
\hline & $24 / 06$ & $\mathrm{U}+\mathrm{W}$ & & & 8 & 1 & & 1 & 1 & 1 & 1 \\
\hline & & $\mathrm{U}$ & & & 6 & 1 & & 1 & 1 & 1 & 1 \\
\hline & & $\mathrm{W}$ & 2 & & 2 & 1 & & 1 & 1 & 1 & 1 \\
\hline \multirow[t]{2}{*}{ CB2 } & $3 / 06$ & $\mathrm{U}$ & & & 3 & 1 & & 1 & 1 & 1 & 1 \\
\hline & $12 / 06$ & $\mathrm{U}$ & & & 7 & 3 & $5(1-7)$ & 1.81 & 1.99 & 0.50 & $0.54(0.05)$ \\
\hline \multirow[t]{7}{*}{ CB4 } & $17 / 06$ & $\mathrm{U}$ & & & 16 & 1 & & 1 & 1 & 1 & 1 \\
\hline & $24 / 06$ & $\mathrm{U}+\mathrm{W}$ & & & 36 & 1 & & 1 & 1 & 1 & 1 \\
\hline & & $\mathrm{U}$ & & & 26 & 1 & & 1 & 1 & 1 & 1 \\
\hline & & $\mathrm{W}$ & 10 & & 10 & 1 & & 1 & 1 & 1 & 1 \\
\hline & $01 / 07$ & $U+W$ & & & 25 & 1 & & 1 & 1 & 1 & 1 \\
\hline & & $\mathrm{U}$ & & & 13 & 1 & & 1 & 1 & 1 & 1 \\
\hline & & $\mathrm{W}$ & 12 & & 12 & 1 & & 1 & 1 & 1 & 1 \\
\hline \multirow[t]{4}{*}{ CB5 } & $17 / 06$ & $\mathrm{U}+\mathrm{W}$ & & & 12 & 1 & & 1 & 1 & 1 & 1 \\
\hline & & $\mathrm{U}$ & & & 6 & 1 & & 1 & 1 & 1 & 1 \\
\hline & & $\mathrm{W}$ & 6 & & 6 & 1 & & 1 & 1 & 1 & 1 \\
\hline & $24 / 06$ & $\mathrm{U}$ & & & 6 & 2 & 6 & 2 & 2.27 & 0.44 & $0.48(0.16)$ \\
\hline Average & & All & & & $11.18^{\dagger}$ & $1.53^{+}$ & 6.4 & $1.18^{\ddagger}$ & $1.16^{\ddagger}$ & $0.86^{+}$ & $0.86^{+}$ \\
\hline SE & & All & & & 2.13 & 0.17 & & 0.09 & 0.12 & 0.05 & 0.008 \\
\hline Average & & $\mathrm{U} / \mathrm{W}$ & & & & & & & & $0.90 / 0.92$ & $0.87 / 0.88$ \\
\hline SE & & $\mathrm{U} / \mathrm{W}$ & & & & & & & & $0.09 / 0.07$ & $0.02 / 0.02$ \\
\hline
\end{tabular}

*Calculated by jackknifing over loci.

${ }^{+}$Arithmetic average.

${ }^{\ddagger}$ Harmonic average.

our study plot, as only two of 53 clones could be recovered from multiple host plants, (ii) there was partial genetic differentiation among aphids collected from different parts of the same plant, and that (iii) relatedness values were not correlated with distance, implying that colonies from neighbouring plants were not more genetically related than those from plants growing further apart and that winged or apterous morphs therefore did not seem to have a preference to colonise nearby plants at the spatial scale we looked at.
Although overall we found clonal diversity in $A$. $f a-$ bae colonies to be relatively low, large variation could be observed in the per colony estimates (Tables 2-4). What factors could explain this variation? First, our results show that the degree of clonal mixing was not related to colony size, the presence or absence of predators and whether colonies were ant tended or not. Interestingly, however, we found that in A. f. cirsiiacanthoidis, clonal diversity increased over the lifetime of a given colony (Fig. 2). This implies that clonal mixing 


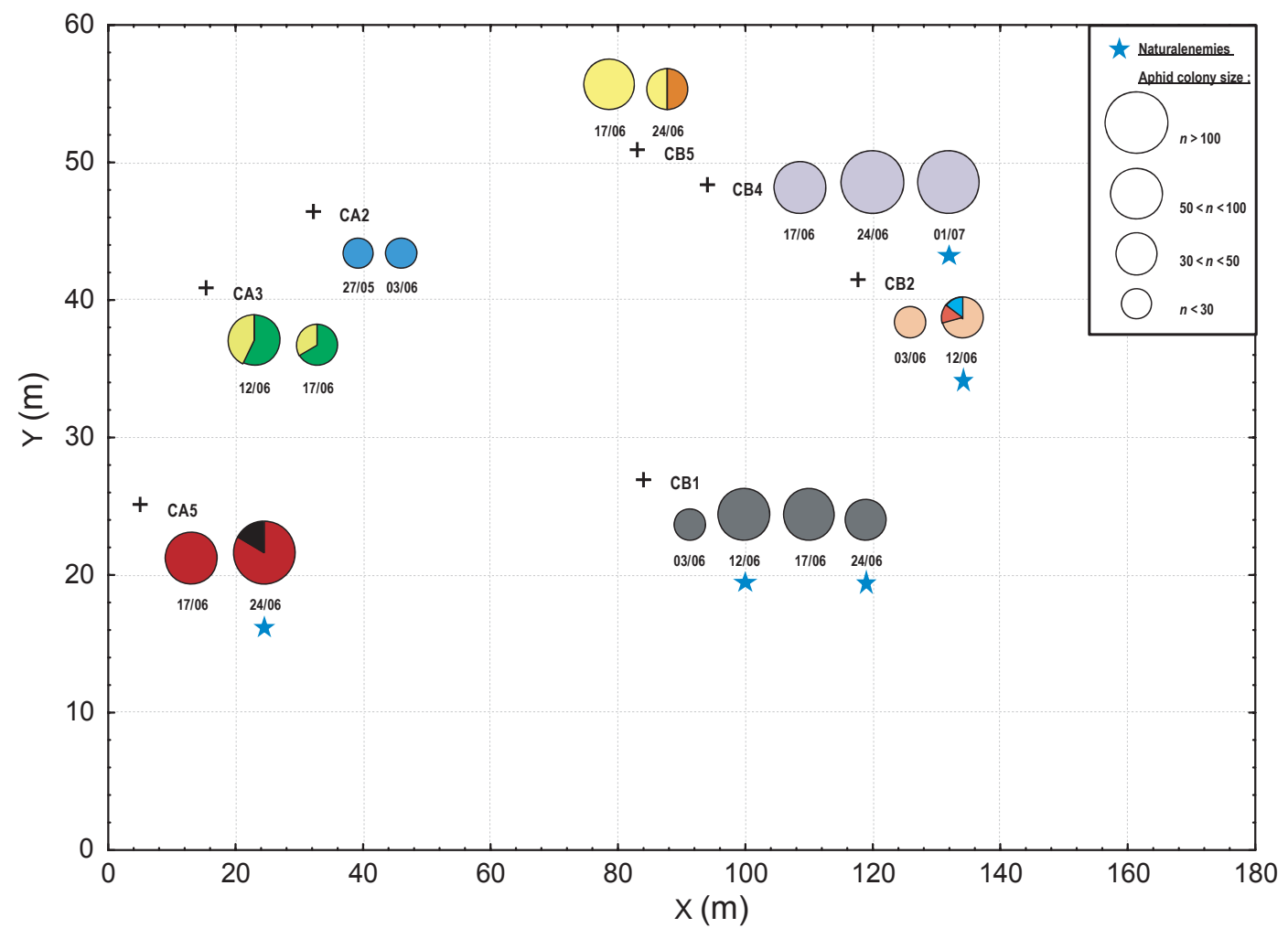

Fig. 2 Genetic structure of the Aphis fabae cirsiiacanthoidis colonies that were studied on plants which were sampled repeatedly over time, showing the location within the study plot, the plant codes, sampling dates and the presence or absence of ants and natural enemies. The sizes of the pie charts are proportional to the estimated aphid colony sizes, and the sectors display the proportional representation of each clone, whereby different colours are used for each clone.

primarily resulted from the joining of pre-existing colonies as opposed to via simultaneous host colonisation by several foundresses, similar to the situation in Macrosiphoniella tanacetaria, where winged morphs were also found to primarily immigrate into already existing colonies (Loxdale et al. 2011). Nevertheless, the average clonal diversity on a given plant was not correlated with seasonal progression. This went counter to our hypothesis that clonal diversity should increase with the progression of the season owing to the greater scarcity of uncolonised host plants towards the end of the season, which would force winged aphids to join pre-existing colonies. Nevertheless, these results could be explained if the influx of new clones in colonies across the season balanced with the disappearance, because of migration or mortality, of clones which were previously present. In fact, a study on the obligate ant mutualist $T$. quercicola even documented a decrease in clonal diversity throughout the season (Yao \& Akimoto 2009; Yao 2010), which was shown to be attributed to a combination of clonal erosion and the inhibition of the migration of alates by the ants, which in this species probably provides a selective advantage in the protection against predators (Yao 2010). Similarly, Loxdale et al. (2011) found that in M. tanacetaria, the per colony clonal diversity decreased as the season progressed. This was probably caused by clonal selection, combined with the fact that this species uses a single host to complete its whole life cycle. The latter situation is different from that in A. fabae, where a large number of secondary hosts are colonised during the season and clones migrate over much larger spatial scales. In addition, A. fabae is only a facultative mutualist and can thrive without ants, implying that the selective advantage of obtaining protection against predators would be of lesser importance than for T. quercicola.

One important question that arises from our study is which factors favour aphids to engage in clonal mixing as opposed to forming pure single-clone colonies. This is particularly pressing given that intuitively, mixing with another clone would only be expected to increase competition for resources. The simplest explanation for why clonal mixing could be favoured is that joining another clone is beneficial when the cost of growing in a mixed colony would be lower than the cost of searching for a new 'empty' plant to colonise (Dixon 1998). Nevertheless, this explanation is not supported by our data given that clonal mixing already occurred very 
early on in the season, when many vacant plants were still available, and that the degree of clonal mixing did not increase as the season progressed. An alternative explanation could be that some Allee effect is at play, which results in joining another colony to be directly beneficial (Allee 1931; Courchamp \& Macdonald 2001; Angulo et al. 2007; Berec et al. 2007; Vercken et al. 2011). For example, it could be that by mixing, the aphids would be able to more easily build up a large colony, which would more likely be tended by ants (Stadler et al. 2003), that they could obtain benefits via a predator dilution effect (Turchin \& Kareiva 1989; Krause \& Ruxton 2002), that they could use the presence of other aphids as cues to find the best feeding sites or seek out plants with little aphid resistance and poor chemical defences (Fletcher 2006), or that they could affect plant metabolism in a way that would result in enhanced food availability and higher aphid growth rates when they occurred in small groups (Way \& Banks 1967; Dixon \& Wratten 1971; Qureshi \& Michaud 2005; Michaud et al. 2006). A. fabae is known to select host plants at a distance based on visual (David \& Hardie 1988) and olfactory cues (Nottingham et al. 1991; Pickett et al. 1992; Powell \& Hardie 2001; Webster et al. 2008), as well as gustatory cues after the aphids have landed on a given plant (Powell et al. 1999). In addition, it is likely that $A$. fabae also uses information about the presence of conspecifics in selecting a suitable host plant, given that at least various other bug species, such as Lygus hesperus and L. rugulipennis, have been shown to detect suitable host plant colonised by rare pioneers, as well as avoid host plants which have already been heavily exploited by others (Blackmer et al. 2004; Frati et al. 2008). Because aphids are known to be able to assess the local neighbourhood, for example in the context of the emission of alarm pheromones (Verheggen et al. 2009), it is likely that they too have the capacity to infer whether a given plant is already occupied or not. A deliberate choice to mix with other clones to obtain direct benefits was supported by the fact that some of the alates joined existing colonies, even when many unoccupied plants were available in the local neighbourhood. A third hypothesis is that some clones would benefit from mixing with clones that are better at attracting mutualistic ants or at detecting predators. This hypothesis also obtained some support by the fact that we recently found that ca. half of all $A$. $f$. fabae clones do not invest in producing the ant attractant sugar melezitose (A. Vantaux, W. Van den Ende, J. Billen, T. Wenseleers, unpublished results), and that mixing with high-melezitose secreting clones would be expected to be a profitable way for low-melezitose secreting clones to benefit from ant attendance without having to invest in the cost of producing the com- pound. Future experiments, however, would be required to determine in more detail which of these different hypotheses best explain the occurrence of clonal mixing in A. fabae.

Overall, the important result of our study is that it shows that the genetic structure of natural aphid colonies does not always correspond to the typical pattern of monoclonality, that is so often assumed in the literature (Mackenzie 1996; Hodgson 2001; Wu et al. 2010). This is significant, given that clonal mixing is expected to have important consequences for aphid ecology and evolution, for example with respect to the evolution of dispersal and the timing of the production of alates (Hamilton \& May 1977; Perrin \& Goudet 2001), the costs and benefits of group living (Krause \& Ruxton 2002), competition over reproduction or over the degree of investment in costly traits required to maintain the ant-aphid mutualism (Stadler \& Dixon 2005). In the future, more detailed experiments aimed at measuring the fitness costs and benefits of clonal mixing as well as the effect of clonal mixing on their mutualistic interaction with ants would be of great interest.

\section{Acknowledgements}

We thank Koenraad Muylaert for providing access to the field site and the FWO-Flanders for financial support.

\section{References}

Abbot P (2009) On the evolution of dispersal and altruism in aphids. Evolution, 63, 2687-2696.

Abbot P, Withgott JH, Moran NA (2001) Genetic conflict and conditional altruism in social aphid colonies. Proceedings of the National Academy of Sciences of the United States of America, 98, 12068-12071.

Allee WC (1931) Animal Aggregations, A Study in General Sociology. The University Chicago Press, Chicago, IL.

Angulo E, Roemer GW, Berec L, Gascoigne J, Courchamp F (2007) Double allee effects and extinction in the island fox. Conservation Biology, 21, 1082-1091.

Arnaud-Haond S, Belkhir K (2007) Genclone: a computer program to analyse genotypic data, test for clonality and describe spatial clonal organization. Molecular Ecology Notes, 7, 15-17.

Berec L, Angulo E, Courchamp F (2007) Multiple Allee effects and population management. Trends in Ecology \& Evolution, 22, 185-191.

Blackmer JL, Rodriguez-Saona C, Byers JA, Shope KL, Smith JP (2004) Behavioral response of Lygus hesperus to conspecifics and headspace volatiles of alfalfa in a Y-tube olfactometer. Journal of Chemical Ecology, 30, 1547-1564.

Braendle C, Davis GK, Brisson JA, Stern DL (2006) Wing dimorphism in aphids. Heredity, 97, 192-199.

Coeur d'Acier A, Sembene M, Audiot P, Rasplus JY (2004) Polymorphic microsatellites loci in the black Aphid, Aphis 
fabae Scopoli, 1763 (Hemiptera, Aphididae). Molecular Ecology Notes, 4, 306-308.

Courchamp F, Macdonald DW (2001) Crucial importance of pack size in the African wild dog Lycaon pictus. Animal Conservation, 4, 169-174.

David CT, Hardie J (1988) The visual responses of free-flying summer and autumn forms of the black bean aphid, Aphis fabae, in an automated flight chamber. Physiological Entomology, 13, 277-284.

De Barro PJ, Sherratt TN, Carvalho GR et al. (1994) An analysis of secondary spread by putative clones of Sitobion avenae within a Hampshire wheat field using the multilocus (GATA)4 probe. Insect Molecular Biology, 3, 253-260.

De Meester L, Vanoverbeke J (1999) An uncoupling of male and sexual egg production leads to reduced inbreeding in the cyclical parthenogen Daphnia. Proceedings of the Royal Society of London Series B-Biological Sciences, 266, 2471-2477.

Detrain C, Verheggen FJ, Diez L, Wathelet B, Haubruge E (2010) Aphid-ant mutualism: how honeydew sugars influence the behaviour of ant scouts. Physiological Entomology, 35, 168-174.

Dixon AFG (1977) Aphid ecology: life-cycles, polymorphism, and population regulation. Annual Review of Ecology and Systematics, 8, 329-353.

Dixon AFG (1998) Aphid Ecology: An Optimization Approach, 2nd edn. Chapman and Hall, London.

Dixon AFG, Agarwala BK (1999) Ladybird-induced life-history changes in aphids. Proceedings of the Royal Society of London Series B-Biological Sciences, 266, 1549-1553.

Dixon AFG, Wratten SD (1971) Laboratory studies on aggregation, size and fecundity in black bean aphid, Aphis fabae Scop. Bulletin of Entomological Research, 6, 97-111.

Fenton B, Woodford JAT, Malloch G (1998) Analysis of clonal diversity of the peach-potato aphid, Myzus persicae (Sulzer), in Scotland, UK and evidence for the existence of a predominant clone. Molecular Ecology, 7, 1475-1487.

Ferrari J, Via S, Godfray HCJ (2008) Population differentiation and genetic variation in performance on eight hosts in the pea aphid complex. Evolution, 62, 2508-2524.

Fischer MK, Hoffmann KH, Völkl W (2001) Competition for mutualists in an ant-homopteran interaction mediated by hierarchies of ant attendance. Oikos, 92, 531-541.

Fletcher RJ (2006) Emergent properties of conspecific attraction in fragmented landscapes. American Naturalist, 168, 207-219.

Frank SA (1986) Dispersal polymorphisms in subdivided populations. Journal of Theoretical Biology, 122, 303-309.

Frati F, Salerno G, Conti E, Bin F (2008) Role of the plantconspecific complex in host location and intra-specific communication of Lygus rugulipennis. Physiological Entomology, 33, 129-137.

Gauffre B, D'Acier AC (2006) New polymorphic microsatellite loci, cross-species amplification and PCR multiplexing in the black aphid, Aphis fabae Scopoli. Molecular Ecology Notes, 6, 440-442.

Guillemaud T, Mieuzet L, Simon JC (2003) Spatial and temporal genetic variability in French populations of the peach-potato aphid, Myzus persicae. Heredity, 91, 143-152.

Hamilton WD (1964a) Genetical evolution of social behaviour 1. Journal of Theoretical Biology, 7, 1-16.

Hamilton WD (1964b) Genetical evolution of social behaviour 2. Journal of Theoretical Biology, 7, 17-52.
Hamilton WD (1987) Kinship, recognition, disease and intelligence: constraints of social evolution. In: Animal Societies: Theories \& Facts (eds Ito Y, Brown JL, Kikkawa J), pp. 81-102. Japan Scientific Societies Press, Tokyo.

Hamilton WD, May RM (1977) Dispersal in stable habitats. Nature, 269, 578-581.

Hardy OJ, Vekemans X (2002) SPAGEDi: a versatile computer program to analyse spatial genetic structure at the individual or population levels. Molecular Ecology Notes, 2, 618-620.

Harrington R, Taylor LR (1990) Migration for survival: finescale population redistribution in an Aphid, Myzus persicae. Journal of Animal Ecology, 59, 1177-1193.

Harrison RG (1980) Dispersal polymorphisms in insects. Annual Review of Ecology and Systematics, 11, 95-118.

Harrison JS, Mondor EB (2011) Evidence for an invasive aphid "superclone": extremely low genetic diversity in Oleander aphid (Aphis nerii) populations in the Southern United States. PLoS ONE, 6, e17524.

Hatano E, Kunert G, Weisser WW (2010) Aphid wing induction and ecological costs of alarm pheromone emission under field conditions. PLOS ONE, 5, e11188.

Hodgson C (1991) Dispersal of apterous aphids (Homopetera, aphididae) from their host plant and its significance. Bulletin of Entomological Research, 81, 417-427.

Hodgson DJ (2001) Monoclonal aphid colonies and the measurement of clonal fitness. Ecological Entomology, 26, 444448.

Howard MT, Dixon AFG (1992) The effect of plant phenology on the induction of alatae and the development of populations of Metopolophium dirhodum (Walker), the rose grain aphid, on winter wheat. Annals of Applied Biology, 120, 203-213.

Johnson PCD, Whitfield JA, Foster WA, Amos W (2002) Clonal mixing in the soldier-producing aphid Pemphigus spyrothecae (Hemiptera: Aphididae). Molecular Ecology, 11, 1525-1531.

Krause J, Ruxton G (2002) Living in Groups. Oxford University Press, New York.

Kunert G, Otto S, Rose USR, Gershenzon J, Weisser WW (2005) Alarm pheromone mediates production of winged dispersal morphs in aphids. Ecology Letters, 8, 596-603.

Kunert G, Trautsch J, Weisser WW (2007) Density dependence of the alarm pheromone effect in pea aphids, Acyrthosiphon pisum (Sternorrhyncha: Aphididae). European Journal of Entomology, 104, 47-50.

Kunert G, Schmoock-Ortlepp K, Reissmann U, Creutzburg S, Weisser WW (2008) The influence of natural enemies on wing induction in Aphis fabae and Megoura viciae (Hemiptera: Aphididae). Bulletin of Entomological Research, 98, 57-62.

Lande R (1996) Statistics and partitioning of species diversity, and similarity among multiple communities. Oikos, 76, 5-13.

Lees AD (1966) The control of polymorphism in aphids. In: Advances in Insect Physiology (eds Beament JWL, Treherne JE, Wigglesworth VB), pp. 207-277. Academic Press, London.

Loxdale HD (2008) The nature and reality of the aphid clone: genetic variation, adaptation and evolution. Agricultural and Forest Entomology, 10, 81-90.

Loxdale HD, Brookes CP (1990) Temporal genetic stability within and restricted migration (gene flow) between local populations of the blackberry-grain aphid Sitobion fragariae in South-East England. Journal of Animal Ecology, 59, 497514 . 
Loxdale HD, Massonnet B, Schofl G, Weisser WW (2011) Evidence for a quiet revolution: seasonal variation in colonies of the specialist tansy aphid, Macrosiphoniella tanacetaria (Kaltenbach) (Hemiptera: Aphididae) studied using microsatellite markers. Bulletin of Entomological Research, 101, 221-239.

Mackenzie A (1996) A trade-off for host plant utilization in the black bean aphid, Aphis fabae. Evolution, 50, 155-162.

Massonnet B, Weisser WW (2004) Patterns of genetic differention between populations of the specialized herbivore Macrosiphoniella tanacetaria (Homoptera, Aphididae). Heredity, 93, 577-584.

Michaud JP, Jyoti JL, Qureshi JA (2006) Positive correlation of fitness with group size in two biotypes of Russian wheat aphid (Homoptera: Aphididae). Journal of Economic Entomology, 99, 1214-1224.

Minks AK, Harrewijn P (1987) Aphids. Their Biology, Natural Enemies and Control. Elsevier, Amsterdam, The Netherlands.

Moran NA (1992) The evolution of aphid life cycles. Annual Review of Entomology, 37, 321-348.

Mousseau TA, Dingle H (1991) Maternal effects in insect life histories. Annual Review of Entomology, 36, 511-534.

Müller CB, Williams IS, Hardie J (2001) The role of nutrition, crowding and interspecific interactions in the development of winged aphids. Ecological Entomology, 26, 330-340.

Nielsen R, Tarpy DR, Reeve HK (2003) Estimating effective paternity number in social insects and the effective number of alleles in a population. Molecular Ecology, 12, 3157-3164.

Nottingham SF, Hardie J, Dawson GW et al. (1991) Behavioral and electrophysiological responses of aphids to host and nonhost plant volatiles. Journal of Chemical Ecology, 17, 12311242.

Offenberg J (2001) Balancing between mutualism and exploitation: the symbiotic interaction between Lasius ants and aphids. Behavioral Ecology and Sociobiology, 49, 304-310.

Ozaki K (1995) Intergall migration in aphids; a model and a test of ESS dispersal rate. Evolutionary Ecology, 9, 542-549.

Perrin N, Goudet J (2001) Inbreeding, kinship, and the evolution of natal dispersal. In: Dispersal (eds Clobert J, Danchin E, Dhondt AA, Nichols JD), pp. 123-142. Oxford University Press, Oxford.

Pickett JA, Wadhams LJ, Woodcock CM, Hardie J (1992) The chemical ecology of aphids. Annual Review of Entomology, 37, 67-90.

Pike N, Foster WA (2008) The ecology of altruism in a clonal insect. In: Ecology of Social Evolution (eds Korb J, Heinze J), pp. 37-56. Springer-Verlag, Berlin.

Plantegenest M, Kindlmann P (1999) Evolutionarily stable strategies of migration in heterogeneous environments. Evolutionary Ecology, 13, 229-244.

Powell G, Hardie J (2001) The chemical ecology of aphid host alternation: how do return migrants find the primary host plant? Applied Entomology and Zoology, 36, 259-267.

Powell G, Maniar SP, Pickett JA, Hardie J (1999) Aphid responses to non-host epicuticular lipids. Entomologia Experimentalis Et Applicata, 91, 115-123.

Queller DC, Goodnight KF (1989) Estimating relatedness using genetic markers. Evolution, 43, 258-275.

Qureshi JA, Michaud JP (2005) Comparative biology of three cereal aphids on TAM 107 wheat. Environmental Entomology, 34, 27-36.
Ronce O, Gandon S, Rousset F (2000) Kin selection and natal dispersal in an age-structured population. Theoretical Population Biology, 58, 143-159.

Shibao H (1998) Social structure and the defensive role of soldiers in a eusocial bamboo aphid, Pseudoregma bambucicola (Homoptera: Aphididae): a test of the defenceoptimization hypothesis. Researches on Population Ecology, 40, 325-333.

Shibao H (1999) Reproductive schedule and factors affecting soldier production in the eusocial bamboo aphid Pseudoregma bambucicola (Homoptera, Aphididae). Insectes Sociaux, 46, 378-386.

Shufran KA, Black WC, Margolies DC (1991) DNA fingerprinting to study spatial and temporal distributions of an aphid, Schizaphis graminum (Homoptera: Aphididae). Bulletin of Entomological Research, 81, 303-313.

Simon J-C, Stoeckel S, Tagu D (2010) Evolutionary and functional insights into reproductive strategies of aphids. Comptes Rendus Biologies, 333, 488-496.

Sloggett JJ, Weisser WW (2002) Parasitoids induce production of the dispersal morph of the pea aphid, Acyrthosiphon pisum. Oikos, 98, 323-333.

Stadler B, Dixon AFG (1998) Costs of ant attendance for aphids. Journal of Animal Ecology, 67, 454-459.

Stadler B, Dixon AFG (1999) Ant attendance in aphids: why different degrees of myrmecophily? Ecological Entomology, 24, 363-369.

Stadler B, Dixon AFG (2005) Ecology and evolution of aphidant interactions. Annual Review of Ecology Evolution and Systematics, 36, 345-372.

Stadler B, Dixon AFG, Kindlmann P (2002) Relative fitness of aphids: effects of plant quality and ants. Ecology Letters, 5, 216-222.

Stadler B, Kindlmann P, Smilauer P, Fiedler K (2003) A comparative analysis of morphological and ecological characters of European aphids and lycaenids in relation to ant attendance. Oecologia, 135, 422-430.

Stern DL, Foster WA (1996) The evolution of soldiers in aphids. Biological Reviews of the Cambridge Philosophical Society, 71, 27-79.

Stroyan HLG (1984) Aphids-Pterocommatinae and Aphidinae (Aphidini), Homoptera, Aphididae. Royal Entomological Society of London, London.

Sutherland ORW (1969) The role of crowding in the production of winged forms by two strains of the pea aphid, Acyrthosiphon pisum. Journal of Insect Physiology, 15, 13851410.

Taylor PD (1988) An inclusive fitness model for dispersal of offspring. Journal of Theoretical Biology, 130, 363-378.

Turchin P, Kareiva P (1989) Aggregation in Aphis varians: an effective strategy for reducing predation risk. Ecology, 70, 1008-1016.

Vanlerberghe-Masutti F, Chavigny P, Fuller SJ (1999) Characterization of microsatellite loci in the aphid species Aphis gossypii Glover. Molecular Ecology, 8, 693-695.

Vercken E, Kramer AM, Tobin PC, Drake JM (2011) Critical patch size generated by Allee effect in gypsy moth, Lymantria dispar (L.). Ecology Letters, 14, 179-186.

Verheggen FJ, Haubruge E, De Moraes CM, Mescher MC (2009) Social environment influences aphid production of alarm pheromone. Behavioral Ecology, 20, 283-288. 
Via S (1991) The genetic structure of host plant adaptation in a spatial patchwork: demographic variability among reciprocally transplanted pea aphid clones. Evolution, 45, 827-852.

Via S (2009) Natural selection in action during speciation. Proceedings of the National Academy of Sciences of the United States of America, 106, 9939-9946.

Völkl W, Woodring J, Fischer M, Lorenz MW, Hoffmann KH (1999) Ant-aphid mutualisms: the impact of honeydew production and honeydew sugar composition on ant preferences. Oecologia, 118, 483-491.

Walsh PS, Metzger DA, Higuchi R (1991) Chelex-100 as a medium for simple extraction of DNA for PCR-based typing from forensic material. BioTechniques, 10, 506-513.

Way MJ, Banks CJ (1967) Intra-specific mechanisms in relation to the natural regulation of numbers of Aphis fabae Scop. Annals of Applied Biology, 59, 189-205.

Webster B, Bruce T, Dufour S et al. (2008) Identification of volatile compounds used in host location by the black bean aphid, Aphis fabae. Journal of Chemical Ecology, 34, 1153-1161.

Weir BS, Cockerham CC (1984) Estimating F-statistics for the analysis of population structure. Evolution, 38, 1358-1370.

Weisser WW, Braendle C, Minoretti N (1999) Predator-induced morphological shift in the pea aphid. Proceedings of the Royal Society of London Series B-Biological Sciences, 266, 1175-1181.

Wilson ACC, Sunnucks P, Hales DF (1999) Microevolution, low clonal diversity and genetic affinities of parthenogenetic Sitobion aphids in New Zealand. Molecular Ecology, 8, 16551666.

Woodring J, Wiedemann R, Fischer MK, Hoffmann KH, Völkl W (2004) Honeydew amino acids in relation to sugars and their role in the establishment of ant-attendance hierarchy in eight species of aphids feeding on tansy (Tanacetum vulgare). Physiological Entomology, 29, 311-319.

Wu GM, Boivin G, Brodeur J, Giraldeau LA, Outreman Y (2010) Altruistic defence behaviours in aphids. BMC Evolutionary Biology, 10, 19.

Yao I (2010) Contrasting patterns of genetic structure and dispersal ability in ant-attended and non-attended Tuberculatus aphids. Biology Letters, 6, 282-286.

Yao I, Akimoto S (2009) Seasonal changes in the genetic structure of an aphid-ant mutualism as revealed using microsatellite analysis of the aphid Tuberculatus quercicola and the ant Formica yessensis. Journal of Insect Science, 9, 18.

This study forms part of the $\mathrm{PhD}$ research of A.V. on conflict and cooperation in ant-aphid mutualisms, carried out at the Laboratory of Entomology at the University of Leuven. J.B. and T.W. co-direct this lab. Both have worked primarily in the areas of chemical ecology and social evolution, using social insects as the prime model system. The present study fits into a recently initiated strand of research on the evolution of interspecific mutualisms.

\section{Data accessibility}

Sample locations and microsatellite data: DRYAD entry doi:10.5061/dryad.tp3g0. 